\title{
De roeping door het evangelie
}

\author{
H. van den Belt
}

\begin{abstract}
According to a common view, the doctrine of the divine calling to salvation -along with the distinction between the outward calling and the inward or effectual calling - is specific for the Reformed tradition. This article, however, argues that the distinction is a catholic one, because it is rooted in the New Testament and from Augustine onward was common in Medieval theology. The early Reformation saw the calling as a proclamation of the Gospel - together with the Law - and emphasized the proclamation of the promises in the form of absolution for the true believers. In the polemics on predestination Calvin increasingly stressed the inner work of the Spirit as mark of election. Reformed Orthodoxy defined the inner calling as an effectual calling; the work of the Spirit is essentially the effect of the preaching of the gospel. In the later pietistic understanding the duplex vocatio became intertwined with the modern distinction between subject and object.
\end{abstract}

\section{Inleiding}

Hoe velerlei roeping is er? Tweeërlei: een uitwendige en een inwendige roeping. Waardoor geschiedt de uitwendige roeping? Door Gods Woord.

Waardoor geschiedt de inwendige roeping? Door Gods Geest.

Is de uitwendige roeping alleen niet genoeg tot bekering? Neen.

Wat moet er dan nog bijkomen? De inwendige roeping.

Wie worden dan inwendig geroepen? Alleen de uitverkorenen.

Wat is de inwendige roeping? Een krachtige verandering van de mens. ${ }^{1}$

De staccatoachtige vragen en antwoorden van Abraham Hellenbroek (16581731) zijn niet alleen kenmerkend voor de wijze waarop generaties van catechisanten kennismaakten met de leer van de vocatio maar ook typerend voor de wijze waarop velen tegen het onderscheid tussen de uitwendige en inwendige roeping aankijken. Het zou gaan om een latere versmalling van de gereformeerde theologie die Woord en Geest uit elkaar trekt en de inwendige roeping ziet als de wedergeboorte die alleen aan de uitverkorenen ten deel valt. De Reformatie zou heel anders over de roeping gesproken hebben. Het onder-

1 Abraham Hellenbroek, Voorbeeld der godlyke waarheeden voor eenvoudigen, Rotterdam 1706, hoofdstuk XII, vraag en antwoord 5-7 en 12-15. 
scheid is dan een scholastieke afwijking van de oorspronkelijke reformatorische inzet bij de prediking als verkondiging van de belofte van het evangelie.

Een dogmenhistorische verkenning van de ontwikkeling van de vocatio en van het gebruik van het onderscheid tussen een uiterlijke en de innerlijke roeping laat echter op minstens vier punten een genuanceerd beeld zien: 1) het onderscheid blijkt katholiek te zijn, 2) de Vroege Reformatie verstaat de roeping vooral als verkondiging van de belofte, 3) bij Calvijn komt de nadruk steeds meer op het inwendige werk van de Geest te liggen en 4) de vroege gereformeerde orthodoxie spreekt bij voorkeur van de effectieve of krachtdadige roeping; aanvankelijk is er nog geen sprake van een verinnerlijking.

Het concept van de vocatio is ook voor de hedendaagse theologie van belang omdat daarin de kracht van het gepredikte Woord in de bediening van de verzoening en de verborgen werking van de Heilige Geest samenkomen. Het is een spannende vraag welke accenten vandaag bij de doordenking van de roeping gelegd moeten worden.

\section{Katholieke traditie}

De eerste correctie betreft het idee dat het onderscheid tussen de uitwendige en de inwendige roeping een uitvinding van de latere gereformeerde orthodoxie betreft. Het gaat hier juist om een heel klassiek en katholiek onderscheid, dat terug te voeren is op het werk van Augustinus. Hij maakt in zijn anti pelagiaanse geschriften een onderscheid tussen de algemene roeping en de specifieke roeping van de uitverkorenen:

Als dus het evangelie gepredikt wordt, zijn er die geloven en zijn er die niet geloven. Zij die geloven, horen en leren binnenin zich van de Vader, onder invloed van de prediking van buitenaf. Zij die echter niet geloven, horen en leren niet van binnen. Dat betekent dat het aan de enen gegeven wordt te geloven en aan de anderen niet, want Jezus zegt: "Niemand kan tot Mij komen als de Vader die Mij gezonden heeft, hem niet trekt." (Johannes 6:44).2

2 Augustinus De praedestinatione sanctorum, VIII.15. Vergelijk Aurelius Augustinus, Vier Antipelagiaanse Geschriften, vertaald door I.J. Wisse en R. Debaene, Zoetermeer 2014, 298. Tegenover Simplicianus merkt Augustinus op dat de roeping de goede wil tot stand brengt en dat alleen zij die geschikt bevonden worden gehoor geven; die geschiktheid is gegrond in Gods ontferming. 'Want diegenen waren uitverkoren die geroepen waren op een manier die bij hen paste [congruenter]'. God roept velen, maar ontfermt zich alleen 'over hen die Hij roept op een manier die voor hen geschikt is om geroepen te worden, zodat zij aan die roeping gehoor geven.' Augustinus, Ad Simplicianus 2.13. Aurelius Augustinus, Aan Simplicianus: Over verschillende kwesties, vertaald door Izak Wisse, Zoetermeer 2013, 75-76. 
Augustinus' leerling Prosper van Aquitanië (ca.390-ca.455) werkt de bijbelse gegevens over de spanning tussen Gods roeping van alle mensen en de uitverkiezing verder uit in zijn De vocatione omnium gentium. Hij schrijft onder andere: 'Als het woord van God de oren van het lichaam binnengaat door de dienst van de predikers, paart de werking van Gods kracht zich aan het geluid van de menselijke stem. Hij die het ambt van de prediker bezielt, geeft ook kracht aan het hart van de hoorder.'3

In de Middeleeuwen is het bij de uitleg van Romeinen 8 vrij gebruikelijk om te onderscheiden tussen twee vormen van vocatio. In de Glossa Ordinaria staan citaten uit de bijbelcommentaren van de patres vaak geharmoniseerd naast elkaar; bij Romeinen 8:30 is er sprake van een duplex vocatio:

De uiterlijke roeping (vocatio exterior) geschiedt door de predikers en is zowel van goeden als van kwaden, maar de innerlijke roeping (vocatio interior) is alleen voor de uitverkorenen. Over de uiterlijke roeping wordt gezegd: Velen zijn geroepen, maar weinigen uitverkoren. Door de roeping wordt de predestinatie vervuld. ${ }^{4}$

Daarbij dient wel te worden opgemerkt dat de predestinatie in de middeleeuwse theologie niet altijd werd opgevat in augustijnse zin en dat de innerlijke roeping voor velen niet inhield dat de genade van de Geest onweerstaanbaar was. Niettemin is de bredere dogmenhistorische context wel van belang om het latere gebruik van de terminologie in de gereformeerde theologie te duiden.

De notie dat zonder de werking van de Geest het Woord krachteloos blijft, is katholiek. Hoe kan het ook anders, want het is een bijbelse notie. Het Nieuwe Testament gebruikt het werkwoord roepen ( $\kappa \alpha \lambda \varepsilon \dot{\varepsilon} \omega)$ en de afgeleide woorden vaak in een gezagsverhouding. De genodigden moeten komen, zij moeten gehoorzamen aan hun roeping. ${ }^{5} \mathrm{Er}$ zit in het werkwoord roepen daarnaast ook een persoonlijk element. Hetzelfde woord betekent immers ook 'noemen, een

3 Prosper van Aquitanië, De vocatione omnium gentium, 1.6. Vergelijk de Engelse vertaling Prosper of Aquitaine, The Call of All Nations, vert. door Prudentius De Letter [The Works of the Fathers in Translation, 14], Westminster 1952, 38.

4 'vocavit: Vocatio exterior sit per praedicatores, \& est communis bonorum \& malorum. Interior vcro tantum electorum. De exteriori dicit: Multi sunt vocati, pauci vero electi. Vocatione impletur praedestinatio.' Voor de Latijnse brontekst, zie de scans van de Glossa Ordinaria op lollardsociety.org, geraadpleegd op 5 december 2017. Vergelijk de Engelse vertaling Michael S. Woodward, The Glossa Ordinaria on Romans [Teams Commentary Series], Kalamazoo 2011, 132.

5 Zie voor een bespreking L. Coenen, 'Call', in C. Brown (red.), The New International Dictionary of New Testament Theology, Grand Rapids 1984, 1:271-276. 
naam geven'. Soms is het een combinatie van beide betekenissen; de herder roept de schapen bij name (Joh. 10:3). De woordgroep wordt doorgaans gebruikt voor de roeping die het gewenste resultaat heeft, voor de gerealiseerde roeping, de vocatio efficax. ${ }^{6}$ De geroepen heiligen van Jezus Christus (Rom. 1:6-7) zijn degenen die God liefhebben en die overeenkomstig zijn voornemen geroepen zijn (Rom. 8:28). Uitzondering op die regel vormen de woorden van Christus: velen zijn uitgenodigd, maar weinigen uitverkoren (Matth. 20:16 en 22:14). ${ }^{7}$

De spanning tussen het effectieve karakter van de roeping en het feit dat niet alle genodigde gasten daadwerkelijk komen, heeft in de dogmatische reflectie vanaf de Vroege Kerk geleid tot het onderscheid tussen de vocatio externa en de vocatio interna, tussen de uitwendige roeping door het Woord alleen en de inwendige roeping door Woord en Geest.

\section{Van biechtstoel naar preekstoel}

De bijbelse en katholieke notie van een tweevoudige roeping is op verschillende wijzen verwerkt in de Reformatie. De algemene indruk is dat daarbij de nadruk valt op de uiterlijke roeping door de verkondiging van het Woord. Die indruk is terecht, maar die nadruk is ook ingegeven door de dubbele polemiek met Rome en de spiritualisten.

De soteriologie van de late Middeleeuwen was intrinsiek verweven met de praktijk van de biecht en de absolutie. De heersende gedachte was dat de gelovigen na de afwassing van de erfzonde in de doop voortdurend de cyclus moesten doorlopen van berouw over de zonde, biecht aan de priester, absolutie en genoegdoening of satisfactio, waaruit de oprechtheid van het berouw moest blijken. Alleen zo kon de gelovige terugkeren in de staat van de genade en deelnemen aan de eucharistie. ${ }^{8}$ De gewone leken werden geacht om minstens eenmaal per jaar deze cyclus te doorlopen. De prediking was vooral een oproep tot boetedoening als voorbereiding op de biecht.

Dat verandert met de Reformatie. Daar verschuift de absolutie als het ware

6 A.A. van Ruler is iets te stellig als hij beweert 'dat het Nieuwe Testament alleen en uitsluitend een vocatio efficax, dus een werkzame en gewerkte, gerealiseerde vocatio kent.' A.A. van Ruler 'De vocatione', in: A.A. van Ruler, Christus, de Geest en het heil [Verzameld werk IV-B], Zoetermeer 2011, 312-374, 314. De bewering klopt wel voor de brieven van Paulus.

7 Wie iets breder kijkt dan de woordstam 'roeping', ontdekt natuurlijk wel meer plaatsen waarin naar een ineffectieve of niet per definitie gerealiseerde roeping verwezen wordt, zoals in de gelijkenis van de zaaier of in de woorden van Paulus dat de bekendmaking van de kennis van Christus zowel een doodsstank als een levensgeur kan zijn (2 Kor. 2:16).

8 Voor een heldere uiteenzetting van de penitential cycle, zie Euan Cameron, The European Reformation, Oxford 1991, 14. 
van de biechtstoel naar de preekstoel. Luther onderscheidt in De vrijheid van een christen de inhoud van de Schrift in geboden en beloften, in wet en evangelie. Beide moeten verkondigd worden. De geboden schrijven ons goede werken voor, maar geven geen kracht om die te volbrengen. Als de zondaar zijn onmacht heeft leren kennen, dan komt het andere woord, de belofte en zegt: 'Wilt $\mathrm{u}$ alle geboden vervullen en [...] van uw [...] zonden verlost worden? Welnu, geloof dan in Christus, in Wie Ik u alle genade, gerechtigheid, vrede en vrijheid toezeg. Gelooft $\mathrm{u}$, dan hebt $\mathrm{u}-$ gelooft $\mathrm{u}$ niet, dan hebt $\mathrm{u}$ niet.' ${ }^{9}$ Voor Luther is het Woord het genademiddel bij uitstek.

De nadruk op de verkondiging van het Woord als heilsmiddel is ook kenmerkend voor de gereformeerde reformatie, denk aan de gevleugelde woorden van Heinrich Bullinger in de kantlijn van de Confessio Helvetica Posterior (1566) 'Predicatio verbi Dei est verbum Dei', ${ }^{10}$ 'De prediking van Gods Woord is Gods Woord.'

Het accent op de uiterlijke roeping verbindt de lutherse en gereformeerde reformaties in hun verzet tegen de spiritualisering van de radicale reformatie. De spiritualisten stellen dat de innerlijke werking van de Geest losstaat van de uiterlijke verkondiging van het Woord. De letter is dood, maar de Geest is levend. ${ }^{11}$ In 1529 bereiken Luther en Zwingli in Marburg op veertien punten overeenstemming. Een daarvan stelt dat de Heilige Geest 'aan niemand het geloof of zijn gave geeft zonder voorafgaande prediking, of aanspraak of het Evangelie van Christus, maar alleen door het Woord werkt Hij en schept het geloof waar en in wie Hij wil (Romeinen 10).'12 De nadruk van de Reformatie op de externe roeping is dus te verklaren vanuit de dubbele polemiek met Rome en de radicalen. Maar die inzet betekent niet dat de noodzaak van het werk van de Geest ontkend wordt, integendeel.

9 Martin Luther, WA 7, 24. Zie voor de vertaling Maarten Luther, Door het geloof alleen: Bloemlezing uit zijn werken, vertaald en ingeleid door prof. W.J. Kooiman, Utrecht 1955, 5.

10 W. Niesel, Bekenntnisschriften und Kirchenordnungen der nach Gottes Wort reformierten Kirche, Zürich 1938, 223.

11 Vergelijk de opmerkingen daarover van Johannes Calvijn in de Institutie 1.9.1-3.

12 "Zum Achten, das der heyllig Geyst, ordennlich zureden, nymands sollichem glauben oder seine Gabe gibt on vorgend Predigt oder muntlich wort, oder Euangelion Christi. Sonndern durch und mit sollichem muntlichen Wort, wirckt er und schafft er den glauben, wo und jn wilchen er will, Rom. x." Zie Wilhelm H. Neuser, “Die Marburger Artikel von 1529", in Heiner Faulenbach en Eberhard Busch (red.) Reformierte Bekenntnisschriften 1/1, 1523-1534, Neukirchen 2002, 259-267, 264. Vergelijk over de verhouding tussen Woord en Geest in de protestantste belijdenisgeschriften, Henk van den Belt, 'Word and Spirit in the Confessions of the European Reformation', in Religion and Theology 23 (2016), 95-110. 


\section{Franciscus Lambertus}

Dat blijkt bijvoorbeeld uit het vroegste reformatorische geschrift dat expliciet over de roeping handelt. Het is een geschrift van de onbekende reformator Franciscus Lambertus van Avignon (ca. 1486-1530), die als rondtrekkend praedicator apostolicus van de orde van de franciscanen uit innerlijke overtuiging emigreert naar Wittenberg, daar aan de universiteit doceert en vandaaruit traktaten in het Frans vertaalt om de Reformatie in zijn thuisland te stimuleren.

Luther regelt voor hem een positie in Straatsburg waar hij preekt voor de Franstalige vluchtelingen. Op de Rijksdag van Speyer bevelen zijn Straatsburgse collega's hem bij Filips I van Hessen (1504-1567) aan, die op zoek is naar een theoloog om de Reformatie in Marburg te leiden. Daar geeft hij leiding aan de theologische faculteit van de nieuwe universiteit.

Lambertus schrijft in 1525 een boek met de titel Over de roeping van de gelovigen in het rijk van Christus, dat is de kerk. In het eerste hoofdstuk stelt hij dat de roeping van de gelovigen tweeledig is: 'De eerste is de verlichting waardoor God iemand zo beweegt door Zijn Woord en Geest, dat hij het koninkrijk en de macht van de duivel verlaat en ingaat in het rijk van de genade en barmhartigheid van zijn Zoon. ${ }^{13}$ Hij verwijst naar Johannes 6 - niemand kan komen, tenzij de Vader trekt - en Johannes 10 - de schapen kennen de stem van de goede Herder.

De andere roeping - tot het ambt in de kerk - is een verlichting van de Geest van God en een getuigenis van het Woord van God, waardoor iemand krachtdadig wordt bewogen om andere christenen te onderwijzen en te troosten met de woorden van de waarheid. Zij die zo geroepen zijn zouden liever sterven dan iets anders dan het Woord van God onderwijzen. De ware bisschop, dienaar of profeet in de kerk wordt vooral gekenmerkt door opofferende liefde voor de schapen. Het is interessant dat Lambertus ondanks zijn overgang tot de lutherse reformatie zijn bediening in het verlengde plaatst van zijn roeping als apostolisch prediker.

In het vierde en vijfde hoofdstuk introduceert en ontwikkelt Lambertus het onderscheid tussen de vocatio interna en de vocatio externa. Alleen degenen die zijn uitverkoren worden innerlijk en krachtdadig geroepen tot Christus. In Romeinen 8:30 zie je duidelijk 'dat alleen de uitverkorenen op onveranderlijke wijze, dat wil zeggen overeenkomstig Gods eeuwig voornemen, behoren tot Zijn ecclesia, en dat zij alleen, zoals we al hebben gezegd, innerlijk geroepen worden.' 14

13 Franciscus Lambertus, De Fidelium Vocatione in Regnum Christi, id est, Ecclesiam, Straatsburg $1525,2 b$.

14 Lambertus, De Fidelium Vocatione, 4b. 
De inhoud van de roeping betreft de oproep tot geloofsvertrouwen op God om zo deel te krijgen aan de gerechtigheid van Christus. De rechtvaardigen in eigen oog worden niet geroepen, maar de zondaren, die van alle vleselijke gerechtigheid afstand hebben gedaan. Door het geloof krijgen zij werkelijk deel aan de goddelijke gerechtigheid in Jezus Christus.

De oproep tot boete en berouw verschuift in de Reformatie naar de roeping om door het geloof in te gaan in het koninkrijk van Christus en te delen in de goddelijke gerechtigheid. De Reformatie doorbreekt de cyclus van de penitentie. De gelovige zondaar wordt door de belofte bekleed met de vreemde gerechtigheid van de Verlosser. De vocatio is niet langer een oproep tot verootmoediging en boetedoening, maar een bediening van wet en evangelie van gebod en belofte. In de prediking voltrekt zich de absolutie. Maar die prediking heeft alleen effect bij hen bij wie de Geest het Woord in het hart brengt. De vocatio interna is het door de Geest bewerkte effect van de prediking.

\section{Ontwikkeling bij Johannes Calvijn}

De positie van Johannes Calvijn is vaak geïnterpreteerd vanuit de inzet van de vroege Reformatie bij het belang van de prediking van het uiterlijke Woord. ${ }^{15}$ Dat is begrijpelijk, maar het voorbeeld van Lambertus illustreert dat het voor het verstaan van de vroege Reformatie belangrijker is om breder te kijken en niet bij voorbaat uit te gaan van een verschuiving van de uiterlijke naar de innerlijke roeping.

Bovendien maakt een analyse van de verschillende edities van de Institutie een ontwikkeling zichtbaar in het denken van Calvijn. Hij begint als een trouwe leerling van Augustinus en Luther en plaatst de roeping van meet af aan in het verlengde van de verkiezing. Zo schrijft hij in de eerste editie van de Institutie (1536) bij de uitleg van de twaalf artikelen over de kerk, dat God, als Hij de zijnen roept, rechtvaardigt en verheerlijkt, daarmee zijn eeuwige verkiezing verklaart. ${ }^{16}$ In 1539 werkt hij dit verband verder uit door de zekerheid aangaande de verkiezing te koppelen aan de roeping. God openbaart de

15 Een duidelijk voorbeeld van deze insteek is te vinden in de boeiende studie van Klaas Exalto (1919-2003). Hij zet zich sterk af tegen de gedachte van een aan het geloof voorafgaande wedergeboorte en een ingestorte genade. K. Exalto, De roeping: Een reformatorische bezinning, Amsterdam 1978. Inderdaad zijn die zo bij Calvijn niet te vinden, maar dat neemt niet weg dat de Geneefse reformator wel degelijk en zelfs in toenemend mate spreekt over de innerlijke roeping, zonder die helemaal van de prediking van het Woord los te maken.

16 Jean Calvin, Opera Selecta [OS] 1:86, vergelijk Johannes Calvijn, Institutie 1536: Onderwijs in de christelijke religie, W. van 't Spijker (red.), tweede druk, Houten 2005, 90. 
verkiezing, die anders verborgen blijft, door de roeping. De roeping is het getuigenis (testificatio) van de verkiezing. ${ }^{17}$ Door de roeping van het evangelie waaraan in geloof gehoor gegeven wordt, kunnen de gelovigen zeker zijn van hun verkiezing. Die roeping 'bestaat uit de prediking van het Woord en uit de verlichting door de Geest.'18 De verkiezing is niet afhankelijk van het geloof en dus ook niet van de roeping, maar andersom. Toch kunnen de gelovigen slechts zeker zijn van hun verkiezing als zij beginnen en eindigen met hun roeping. ${ }^{19}$

Dan volgt het bekende beeld van Christus als de spiegel van de verkiezing. Wij kunnen weten dat we uitverkoren zijn als we deel uitmaken van het lichaam van Christus en gemeenschap met Hem hebben. 'Hij heeft ons verder ook de zekere gemeenschap met Hem gegeven doordat Hij in de prediking van het Evangelie getuigd heeft dat Hij ons door de Vader gegeven is om met al Zijn goederen de onze te zijn.' ${ }^{20}$ De verkiezing is onlosmakelijk met de roeping verbonden en als we daarom twijfelen of we wel in de hoede van Christus opgenomen zijn, 'komt Hij ons in die twijfel tegemoet, doordat Hij zich uit eigen beweging als onze Herder aanbiedt en verklaart dat wij tot Zijn schapen gaan behoren, indien wij zijn stem horen. Laten we daarom Christus omhelzen, die ons zo vriendelijk voorgesteld wordt en tegemoet treedt. ${ }^{21}$

$\mathrm{Na}$ deze definitie van de roeping door het evangelie, bespreekt Calvijn enkele tegenwerpingen tegen de gedachte dat zekerheid over de verkiezing en over de zaligheid mogelijk is. Je weet als gelovige immers nooit hoe het met je afloopt en het kan wel lijken alsof je Christus toebehoort, maar dan kun je later nog wel ten val komen. Volgens Calvijn hebben sommigen inderdaad tekenen van de roeping die met die van de uitverkorenen overeenkomen, maar hangen zij Christus niet aan 'met het geloofsvertrouwen in hun hart (cordis fiducia) waarin naar mijn oordeel de zekerheid omtrent onze verkiezing haar bevesti-

17 OS 4:410; deze tekst uit 1539 staat in 1559 in Institutie 3.24.1. Vergelijk Johannes Calvijn, Institutie, of Onderwijzing in de christelijke godsdienst, vertaling C.A. de Niet, Houten 2009, 2:168. De Niet vertaalt getuigenis met 'certificaat'.

18 OS 4:412. Deze tekst uit 1539 is in Institutie 3.24.2 gewijzigd in: 'Zij bestaat namelijk niet alleen uit de prediking van het Woord, maar ook uit de verlichting door de Geest.' Calvijn, Institutie, vertaling De Niet, 2:170-171.

19 OS 4:415. Deze tekst uit 1539 staat uiteindelijk in Institutie 3.24.4.

20 OS 4:416. Deze tekst uit 1539 staat uiteindelijk in Institutie 3.24.5. Calvijn, Institutie, vertaling De Niet, 2:174 heeft 'de zekerheid van de gemeenschap', maar certa communio is ook de gemeenschap zelf.

21 OS 4:416. Deze tekst uit 1539 staat uiteindelijk in Institutie 3.24.6. Vergelijk Calvijn, Institutie, vertaling De Niet, 2:176. 
ging vindt.'22 Een andere tegenwerping betreft het woord van Christus dat velen geroepen, maar weinigen uitverkoren zijn. In deze context maakt Calvijn dan het onderscheid tussen twee soorten roeping, een duplex vocatio.

Er is namelijk een algemene roeping, waarmee God door middel van de uitwendige prediking van het Woord (externa praedicatio verbi) allen in gelijke mate tot zich nodigt [...]. Daarnaast is er de bijzondere roeping die Hij veelal alleen de gelovigen waardig keurt waarbij Hij door de innerlijke verlichting van Zijn Geest (interior sui Spiritus illuminatio) maakt dat het gepredikte Woord een plaats in hun harten verkrijgt. ${ }^{23}$

De bijzondere roeping door de verlichting met de Geest is niet per se zaligmakend of effectief, want soms worden mensen slechts voor een tijd verlicht. Uit de volharding blijkt uiteindelijk pas de effectiviteit van de roeping, zij het dat degenen bij wie die volharding ontbreekt de volle verzekerdheid van het geloofsvertrouwen misten.

Als Calvijn vervolgens de gelijkenis van de bruiloft uitlegt, schrijft hij dat de roeping van de vele genodigden uiteraard slaat op de uiterlijke roeping (externa vocatio) maar dat is niet de roeping waaraan de gelovigen hun verkiezing kunnen aflezen. 'De ene hebben ze immers gemeen met de goddelozen, de andere brengt de Geest van de wedergeboorte (Spiritus regenerationis) met zich mee, die het onderpand en zegel van de toekomstige erfenis is, waarmee onze harten verzegeld worden tot de dag van de Heere.24

Het is wel duidelijk dat Calvijn bij het spreken over de roeping denkt vanuit de verkiezing en het vooral heeft over de bijzondere roeping. Toch beantwoordt hij in 1539 de vraag hoe je via je roeping zeker kunt zijn van je verkiezing door te verwijzen naar de verkondiging van het evangelie en naar de gelovige respons als het getuigenis of het zegel van de Geest. Dat deze roeping innerlijk is of samengaat met de verlichting van de Geest is niet voldoende, dat kan ook bij de huichelaars zo zijn; het komt aan op 'het geloofsvertrouwen van [het] hart (cordis fiducia) waarin [...] de zekerheid omtrent onze verkiezing haar bevestiging vindt.'25

22 OS 4:418. Deze tekst uit 1539 staat uiteindelijk in Institutie 3.24.7. Vergelijk Calvijn, Institutie, vertaling De Niet, 2:177.

23 OS 4:419. Deze tekst uit 1539 staat uiteindelijk in Institutie 3.24.8. Vergelijk Calvijn, Institutie, vertaling De Niet, 2:178.

24 OS 4:420. Deze tekst uit 1539 staat uiteindelijk in Institutie 3.24.8. Vergelijk Calvijn, Institutie, vertaling De Niet, 2:179.

25 OS 4:418. Deze tekst uit 1539 staat uiteindelijk in Institutie 3.24.7. Vergelijk Calvijn, Institutie, vertaling De Niet, 2:177. 


\section{Institutie 1559}

In de laatste editie van de Institutie neemt Calvijn de eerdere teksten vaak integraal over. Maar soms voegt hij ook een aantal elementen toe, waardoor het accent in de laatste editie verschuift van het effectieve samengaan van Woord en Geest, naar de doorslaggevende innerlijke roeping.

Helemaal aan het begin van het hoofdstuk over de roeping (3.24) voegt Calvijn toe dat de prediking van het evangelie geen bewijs van de verkiezing is, omdat zij ook tot de verworpenen komt; 'God onderwijst zijn uitverkorenen echter krachtdadig (efficaciter).'26 Hij verwijst naar Augustinus' De praedestinatione sanctorum (VIII.13), waar de kerkvader stelt dat degenen die tot Christus komen de roeping van de Vader innerlijk gehoord hebben door 'de genade die in het verborgen aan mensenharten geschonken wordt.'27 Door deze toevoeging ligt het accent dus meteen op de innerlijke werking van de Geest.

In 1539 schreef Calvijn dat de roeping 'bestaat uit de prediking van het Woord en uit de verlichting door de Geest', maar in 1559 bestaat de roeping 'niet alleen uit de prediking van het Woord, maar ook uit de verlichting door de Geest.'28 De verworpenen horen wel het Woord, maar wijzen het bewijs van Gods liefde af. 'Verder neemt God, tot roem van Zijn heerlijkheid, ook de krachtdadige werking van Zijn Geest (Spiritus sui efficacia) van hen weg. Deze innerlijke roeping (interior vocatio) is dus een onfeilbaar onderpand van de zaligheid.' 29

Kortom, in plaats van de prediking van het Woord en de gelovige respons door de verlichting van de Geest als geheim van de zekerheid aangaande de

26 Institutie 3.24.8, OS 4:410, vergelijk Calvijn, Institutie, vertaling De Niet, 2:169.

27 Augustinus, De praedestinatione sanctorum, VIII.13. Vergelijk Augustinus, Vier Antipelagiaanse Geschriften, 295-296.

28 Institutie 3.24.2 OS 4:412, vergelijk Calvijn, Institutie, vertaling De Niet, 2:170-171 [cursivering van $\mathrm{HvdB}]$.

29 Institutie 3.24.2 OS 4:412, vergelijk Calvijn, Institutie, vertaling De Niet, 2:171. In de verschillende edities van zijn commentaar op Romeinen is er sprake van een vergelijkbare ontwikkeling. In zijn overigens excellente proefschrift onderschat Pieter Rouwendal de ontwikkeling bij Calvijn met betrekking tot de innerlijke en uiterlijke roeping. Hij stelt dat de voorwaardelijke structuur van de belofte - zonder geloof of innerlijke roeping is er geen effect - al in het commentaar op Romeinen 10:16 aanwezig is. Calvijn voegt echter pas in 1551 toe dat de inwendige roeping, die alleen krachtig en alleen aan de uitverkorenen eigen is, van de uitwendige stem onderscheiden moet worden. Pieter L. Rouwendal, Predestination and Preaching in Genevan Theology from John Calvin to Benedict Pictet [Texts and Studies in Historical Theology, 1], Kampen 2016, 43 n102. Vergelijk CO 49:204 en Johannes Calvijn, Commentarius in Epistolam Pauli Ad Romanos [Ioannis Calvini Opera Recognita, 3, Opera Exegetica Verteris et Novi Testamenti, XIII], Genève 1999, 224. 
verkiezing, treedt nu van meet af aan de innerlijke roeping naar voren als enige blijk van de verkiezing.

Die toevoegingen kunnen tot verwarring leiden. In de eerdere editie had Calvijn betoogd dat er ook bij de verworpenen soms sprake is van een innerlijke roeping of een zekere mate van verlichting door de Geest, maar dan zonder de volle zekerheid die het ware geloof kenmerkt. Omdat hij dat laat staan in de laatste editie, maar tegelijk het accent op de innerlijke roeping als de eigenlijke roeping versterkt, is het onhelder hoe de interior vocatio een onfeilbaar onderpand van de verkiezing kan zijn terwijl de verworpenen soms ook innerlijk geroepen worden.

Calvijn begint als leerling van Augustinus en Luther. Er is geen effect van het Woord zonder de werking van de Geest. Maar gaandeweg wendt Calvijn onder invloed van de polemiek rond de predestinatieleer zich meer en meer tot de vocatio interna. Tegenover de lutheranen - die de Geest onlosmakelijk aan het Woord binden - komt hij op voor de vrijheid en soevereiniteit van de Geest. De uiterlijke middelen zijn slechts instrumenten waardoor de Geest ons met Christus verbindt. Als het meer dan instrumenten zijn, dan maak je er gemakkelijk een afgod van.

Daarbij mag niet vergeten worden dat de verborgen verbinding met Christus - die alleen aan de uitverkorenen wordt geschonken in de inwendige roeping - tot stand komt door middel van de prediking van het Woord. Voor Calvijn is de absolutie - de verkondiging van de genade voor eenieder die gelooft - een wezenlijk onderdeel van de eredienst. In Straatsburg geeft hij haar zelfs een plaats in de liturgie. Na het votum volgt een opwekking tot schuldbelijdenis en een verootmoedigingsgebed. $\mathrm{Na}$ deze belijdenis volgt de absolutie: 'Laat iedereen van u oprecht erkennen dat hij of zij een zondaar is en zich verootmoedigend voor God, geloven dat de hemelse Vader u genadig wil zijn in Jezus Christus. Aan allen die zo berouw hebben en Christus zoeken voor hun zaligheid, verkondig ik de absolutie/dat hun zonden zijn vergeven, in de naam van de Vader, de Zoon en de Heilige Geest. Amen.'30 Daarna worden de tien geboden gezongen, onderbroken door een gebed tussen de eerste

30 OS 2:18-19. Vergelijk K. Deddens, 'Rond de schuldbelijdenis in de liturgie', In die Skriflig 29/3 (1995), 491-529, 498. Hoewel het hem niet lukte om in Genève de absolutie in de liturgie in te voeren, sprak hij de hoop uit dat die elders wel gehandhaafd zou worden. Deddens, 'Rond de schuldbelijdenis', 510. Zie voor de praktijk in Straatsburg René Bornert, La Réforme Protestante Du Culte À Strasbourg au XVie Siècle (1523-1598): Approche Sociologique Et Interprétation Théologique [Studies in Medieval and Reformation Thought, 28], Leiden 1981, 401-407. 
en de tweede tafel; de wet aan het begin van de eredienst is dus al leefregel der dankbaarheid.

Later in Genève ziet Calvijn de absolutie meer als integraal onderdeel van de eredienst en met name van de prediking, maar inhoudelijk is er geen verschuiving. De vocatio externa blijft de toezegging aan allen die in Christus geloven dat hun zonden vergeven zijn. Deze absolutie is alleen effectief als de Geest de gelovige aan Christus verbindt. De prediking is het instrument van de Geest, die de gelovige aan Christus verbindt en doet delen in al zijn weldaden. Enerzijds staat Calvijn dus tegenover het lutherse automatisme van de binding van de Geest aan het Woord, maar anderzijds werkt de Geest wel instrumenteel. ${ }^{31}$

Zoals de positie van Calvijn met betrekking tot het avondmaal als 'symbolisch instrumentalisme' getypeerd kan worden, zo kun je in vergelijkbare zin speken van een instrumentele werking van de prediking van het Woord waaraan de soevereine Geest zich paart. Vergelijk ook wat Calvijn schrijft in zijn reactie op Albert Pighius: 'God schrijft krachtdadig (efficaciter), door Zijn Geest op de harten van de mensen wat Hij niet eerder en niet later maar tegelijk (simul) met Zijn mond tot hun oren spreekt.'32

\section{Reactie op Jacobus Arminius}

Vaak wordt gesteld dat er in de ontwikkeling van de gereformeerde orthodoxie een toenemende verinnerlijking plaatsvindt op het punt van de roeping. De door de Geest krachtige en krachtdadige roeping van het evangelie zou door de scholastiek in een systeem gegoten zijn, waarbij alleen nog aandacht is voor de inwendige roeping in de harten van de uitverkorenen.

Bestudering van de bronnen laat echter iets anders zien. De nadruk verschuift in de discussie met de remonstranten van de innerlijke roeping naar de effectieve of krachtdadige roeping. In zijn allerlaatste Leidse disputatie (25 juli 1609) stelt Arminius dat de uitwendige roeping plaatsvindt door de verkondiging van wet en evangelie, maar

de inwendige roeping door de werking van de Heilige Geest, die het verstand verlicht en het hart raakt opdat er acht geslagen wordt op de dingen die gespro-

31 Brian Gerrish typeert de positie van Calvijn als 'symbolic instrumentalism' naast het 'symbolic memorialism' van Zwingli en het 'symbolic parallelism' van Bullinger. Brian A. Gerrish, 'Sign and reality: The Lord's Supper in the Reformed Confessions', in Brian A. Gerrish, The Old Protestantism and the New: Essays on the Reformation Heritage, Edinburgh 1982, 118-130.

32 CO 6:345. Vergelijk de verwijzing bij Exalto, De roeping, 50, die verwijst naar Herman Bavinck, Roeping en wedergeboorte, Kampen 1903, 80. 
ken worden en opdat er geloof of vertrouwen gehecht wordt aan het woord. De effectieve roeping vindt plaats als de uitwendige en de inwendige roeping samenkomen. ${ }^{33}$

Ook volgens Arminius is er dus een inwendige roeping, maar de effectiviteit van die krachtdadige roeping hangt af van het geloof. 'Het antwoord waarmee aan deze roeping gehoorzaamheid verleend wordt, is door Gods besluit de noodzakelijke en onontbeerlijke voorwaarde om het doel te verkrijgen.' ${ }^{34} \mathrm{Met}$ andere woorden: zonder gelovige instemming komt de effectieve of krachtdadige roeping niet tot haar doel.

Arminius ontkent, volgens een van zijn leerlingen Adriaan Van den Borre (1565-1630), bij de verdediging van deze disputatie de onweerstaanbare kracht van God bij de bekering van zondaren. God voorziet de mens wel van de kracht om aan de roeping gehoor te geven maar of iemand dat ook echt doet is een kwestie van de vrije wil. Er is ook een jezuiet in de aula van de Leidse universiteit op het Rapenburg. Blijkbaar konden rooms-katholieke theologen - ondanks het verbod op de publieke uitoefening van hun religie - toch gewoon aan een academisch debat deelnemen. Gomarus windt zich zo op over de antwoorden die Arminius aan de jezuïet geeft dat hij opmerkt dat zijn collega de deur naar Rome wagenwijd openzet. Arminius ontkent dat stellig. ${ }^{35}$ Het wordt de laatste confrontatie tussen de Leidse kemphanen. Arminius sterft enkele weken later.

Het is opvallend dat in reactie op deze lijn van Arminius, de Dordtse Leerregels enerzijds vasthouden aan de algemene roeping: door de dienst van de verkondigers van deze zeer blijde boodschap van het evangelie 'worden de mensen geroepen tot bekering en het geloof in Christus, de Gekruisigde'

33 Het betreft stelling 11 in Jacobus Arminius, Disputationum theologicarum quarto repetitarum trigesima-quinta, de vocatione hominum ad salutem, Iacobus Bontebal respondent, Leiden 1609. Vergelijk Jacobus Arminius, Disputationes XXIV: De diversis Christianae Religionis capitibus ab ipsomet totidem verbis compositae, Leiden 1609, 271-276. Voor een Engelse vertaling, zie Jacobus Arminius, The Works of James Arminius, vertaald door J. Nichols, 3 delen, Londen, 1825-1875, 1:573. Zie voor de verschillende disputaties in Leiden over de roeping, Henk van den Belt, 'The Vocatio in the Leiden Disputations (1597-1631): The Influence of the Arminian Controversy on the Concept of the Divine Call to Salvation', Church History and Religious Culture 92, (2012), 539-559. Vergelijk ook H. van den Belt, Puur en ongezoet: Gereformeerde orthodoxie in de Synopsis Purioris Theologiae (1625), Baarn 2015, 37-41.

34 Arminius, De vocatione, stelling 10.

35 In een brief aan Simon Episcopius. Johannes Wtenbogaert, Conradus Vorstius en Jacobus Arminius, Praestantium ac eruditorum virorum epistolae ecclesiasticae et theologicae, Amsterdam 1684, 266. 
(I.3). ${ }^{36}$ Maar anderzijds stellen de canones dat God besloten heeft alleen de uitverkorenen met kracht door Christus' Woord en Geest 'tot zijn gemeenschap te roepen en te trekken, ofwel hen met het ware geloof in Hem te begiftigen' (I.7).

Allen die geroepen worden, worden in alle ernst geroepen. Dat velen niet komen, is hun eigen schuld, dat anderen wel komen, moet men 'aan God toeschrijven, die, evenals Hij de zijnen van eeuwigheid in Christus heeft uitverkoren, hen ook zo in de tijd krachtdadig roept, met het geloof en de bekering begiftigt' (III/IV.10). Allen tot wie het evangelie komt worden geroepen, maar alleen de uitverkorenen worden krachtdadig (efficaciter), dat wil zeggen met effect, geroepen. Hier wordt het effect van de roeping dus niet aan de innerlijkheid van de roeping gekoppeld, al stellen de Leerregels wel dat de Geest in de wedergeboorte doordringt tot in het binnenste van de mens en zelfs 'nieuwe hoedanigheden' uitstort in de wil (III/IV.11). Eenzelfde lijn vinden we in de Synopsis Purioris Theologiae:

door de bijzondere roeping (vocatio specialis) roept God sommigen uit het hele menselijke geslacht weg uit de onreinheden van deze wereld naar de bovennatuurlijke kennis van onze Verlosser Jezus Christus en de participatie in zijn zaligmakende weldaden. Hij doet dat door de bediening van het evangelie en de kracht van de Heilige Geest en daarom kan zij een bovennatuurlijke en evangelische roeping genoemd worden. ${ }^{37}$

De bijzondere roeping geschiedt niet alleen uiterlijk door de bediening van het Woord en de sacramenten, maar ook innerlijk door het werk van de Heilige Geest. Of de roeping echter effectief is, hangt af van de wijze waarop beide roepingen samengaan. De Synopsis spreekt dus van een effectief en een ineffectief samenkomen (concursus efficax en inefficax) van de uitwendige en inwendige roeping. De gelijkenis van de zaaier illustreert op welke verschillende wijzen de uitwendige en inwendige roeping samen kunnen gaan. Sommigen - als het zaad op de weg valt - worden door het licht van de waarheid van het evangelie verlicht, maar worden niet bewogen om die te omhelzen. Anderen - als het zaad tussen de doornen valt - laten het licht van de waarheid, die zij in hun ziel ontvangen hebben, verstikken door de zorgen en

36 Voor de vertaling is gebruikgemaakt van K. Zwanepol, Belijdenisgeschriften van de Protestantse Kerk in Nederland, Heerenveen 2009.

37 Synopsis Purioris Theologiae disputatie 30, these 5. Voor de Latijnse tekst en Engelse vertaling zie H. van den Belt (red.), Synopsis Purioris Theologiae / Synopsis of a Purer Theology: Latin Text and English Translation: dl 2, Disputations 24-42 [Studies in Medieval and Reformation Traditions: Texts and Sources, 204/8] Leiden 2016, 2:208-211. 
het plezier van deze wereld. Aan weer anderen - het zaad dat op de rots valt laat de Heilige Geest iets proeven van zijn genade, waardoor hun harten geraakt worden door een kort gevoel van blijdschap.

Als de uitwendige en inwendige roeping effectief samengaan - het zaad dat in de goede aarde valt - 'bewerkt de Heilige Geest de volle overtuiging (Grieks: plèroforia) of het vertrouwen van een levend geloof geworteld in Christus, waardoor zij zich de belofte van de genade, die door het inwendig getuigenis van de Geest verzegeld wordt, vast en volhardend toe-eigenen.' 38

In de ontwikkeling van de gereformeerde orthodoxie is aanvankelijk, vergeleken bij Calvijn, juist sprake van een sterker onderscheid tussen de inwendige roeping en de effectieve of krachtdadige roeping. Om het misverstand uit de weg te ruimen dat het effect van de roeping uiteindelijk toch nog afhankelijk zou zijn van de menselijke instemming wordt de effectiviteit van het werk van de Heilige Geest in de roeping benadrukt.

Uiteindelijk resulteert dat bij sommige latere vertegenwoordigers van de gereformeerde orthodoxie in een vereenzelviging van de krachtdadige roeping met de wedergeboorte of de bekering, die als een onmiddellijk werk van de Geest wordt gezien. Daardoor dreigt de altijd nog wel beleden relatie met de verkondiging van het evangelie in het gedrang te komen. Deze latere ontwikkeling die bijvoorbeeld uit het werk van John Owen (1616-1683) en uit het aangehaalde vragenboekje van Abraham Hellenbroek blijkt, moet in het kader van dit artikel buiten beschouwing blijven. ${ }^{39}$

De aanvankelijke inzet van de gereformeerde orthodoxie bij de synode van Dordrecht beoogt een verheldering te geven van de spanning tussen de uiterlijke verkondiging van het Woord en de innerlijke werking van de Geest die bij Calvijn door de polemiek over de predestinatie steeds sterker in het voordeel van de vocatio interna werd beslist. De innerlijke of de effectieve roeping is het effect van de - door de werking van de Geest krachtig gemaakte - verkondiging van het evangelie op het hart van de uitverkoren gelovigen. Daarin is de vroege gereformeerde orthodoxie duidelijker dan Calvijn.

38 Synopsis Purioris Theologiae, disputatie 30, these 38. Vergelijk Van den Belt, Synopsis of a Purer Theology, 2:222-223.

39 John Owen vat in zijn Pneumatologia de werking van de Heilige Geest in roeping en wedergeboorte als een onmiddellijke vernieuwing van de wil op. De Geest werkt 'internally, immediately, efficiently, in and upon the minds of men in their regeneration.' William $\mathrm{H}$. Goold (red.), The Works of John Owen, Londen 1850-1853, 3:317. Zie voor de roeping bij John Owen, Henk van den Belt 'Vocatio as Regeneration: John Owen's Concept of Effectual Calling' dat binnenkort zal verschijnen onder redactie van W. van Vlastuin en K. Kapic, John Owen between orthodoxy and modernity. 
Drie eeuwen later verdeelt het neocalvinisme in de school van Abraham Kuyper de inwendige roeping in tweeën: het onmiddellijke 'herscheppend roepen Gods in het binnenste van den zondaar' waardoor de zondaar opnieuw geboren wordt en de 'innerlijke roeping of de vocatio interna, die bestaat in de toepassing van Gods Woord aan het hart.' Het eerste is de wedergeboorte, de inplanting van de kiem van het nieuwe leven en het tweede het ontkiemen en tot ontplooiing komen van het zaad van de wedergeboorte. ${ }^{40}$ Vandaag de dag wordt in reformatorische kring de inwendige roeping onder invloed van de latere gereformeerde orthodoxie à la Hellenbroek en de piëtistische nadruk op de ervaring vooral verstaan als een innerlijke doorleving van zonde en genade.

Als in de context van de moderniteit het onderscheid tussen de algemene roeping door het evangelie en de effectieve roeping van de Geest verweven raakt met het onderscheid tussen de objectieve waarheid en de subjectieve kennis van die waarheid, dan leidt dat tot het fundamentele probleem dat de hoorder van het evangelie op zichzelf en op de bij zichzelf waargenomen kenmerken van de genade teruggeworpen wordt. Dat ligt echter niet zozeer aan de scholastieke theologie, maar aan het feit dat die theologie in een veranderde culturele context gekopieerd wordt en een andere betekenis krijgt.

\section{Conclusies}

Het gangbare beeld met betrekking tot de ontwikkeling van de leer van de vocatio in de gereformeerde theologie en met name van de verhouding tussen de prediking van het Woord in de uiterlijke en de werking van de Geest in de innerlijke roeping is eenzijdig. ${ }^{41} \mathrm{Er}$ is in de eerste plaats geen sprake van een specifiek gereformeerde doctrine, maar van een katholiek onderscheid dat teruggaat op het nieuwtestamentische spreken over de roeping als werkzame en gerealiseerde vocatio dat met name via Augustinus in de middeleeuwse theologie doorwerkte. In de context van de cyclus van de biecht werd de roeping daarin voornamelijk verstaan als een oproep tot berouw en bekering. In de tweede plaats hebben we gezien dat de Vroege Reformatie de roeping her-

40 K. Dijk, 'Roeping' in: F.W. Grosheide, J.H. Landwehr, C. Lindeboom en J.C. Rullmann (red.), Christelijke encyclopaedie voor het Nederlandsche volk, 6 delen, Kampen 1926-1931, [eerste druk], 3:753-756, 753. Vergelijk K. Dijk, 'Roeping' in: F.W. Grosheide, G.P. van Itterzon, J. Overduin en W.E. Steunenberg, Christelijke Encyclopedie, tweede geheel herziene druk, 6 delen Kampen, 1956-1961, 5:464-469.

41 De negatieve waardering van de inwendige roeping is vooral typerend voor de Nederlandse context; onlangs verscheen in het Engels de positieve dogmenhistorische en systematische studie over de effectieve of krachtdadige roeping van Jonathan D. Hoglund, Called by Triune Grace: Divine Rhetoric and the Effectual Call, Downers Grove 2016. 
interpreteert als een verkondiging van wet en evangelie waarbij de verkondiging van de beloften de vorm krijgt van de absolutie voor de ware gelovigen. Tegenover Rome en de radicalen ligt de nadruk op de uiterlijke verkondiging van het Woord. De onderscheiding tussen de innerlijke en de uiterlijke roeping gaat, ten derde, de theologie van Calvijn in toenemende mate bepalen, waarbij de innerlijke werking van de Geest gaat functioneren als kenmerk van de verborgen verkiezing. In de context van de arminiaanse twisten geeft de gereformeerde orthodoxie er, in de vierde plaats, de voorkeur aan om de inwendige roeping als effectieve of krachtdadige roeping te definiëren. Het werk van de Geest is in essentie het effect van de verkondiging van het evangelie, hoewel er in de latere gereformeerde orthodoxie en vooral bij het piëtisme opnieuw een verinnerlijking optreedt waarin de duplex vocatio verweven raakt met de moderne scheiding tussen subjectief en objectief.

De vocatio interna is de door de Geest toegepaste vocatio externa. We moeten beide juist in de (post)moderne context heel dicht bijeenhouden. Om het met Van Ruler te zeggen: de vocatio interna is het Woord dat van buiten komt, dat penetreert tot in het hart; naar vorm en naar inhoud hoor ik niets anders dan wat ik vanaf de preekstoel hoor; maar ik hoor het anders.' 42

De worsteling in de katholiek-gereformeerde theologie met de verwoording van de genadeleer heeft bij de bespreking van de roeping gezorgd voor een duidelijk accent op het effect van die roeping. Maar als vocatio uiteindelijk niet meer is dan een 'onmiddellijke' werking van de Geest, dan is het geen echte roeping meer, maar een synoniem voor de wedergeboorte. Het risico daarvan is dat de prediking als middel om dat effect te bewerkstelligen uit het zicht verdwijnt. Of om het met Hellenbroek te zeggen: de uitwendige roeping is niet genoeg, de inwendige moet er nog bijkomen.

Het is jammer dat de begrijpelijke zorg dat het effect van de roeping afhankelijk zou worden gemaakt van de menselijke respons, tot deze versmalling heeft geleid. Het sola gratia biedt juist ruimte aan de prediking. Als geroepen

42 Van Ruler 'De vocatione,' 313. Vergelijk ook zijn prachtige uitleg van de structuur van de prediking: 'Alle mensen worden geroepen, om dit heil in geloof aan te nemen en te ontvangen. Ja, ze worden niet alleen geroepen, hun wordt van Godswege geboden en bevolen, alles wat God schenkt in de gehoorzaamheid van het geloof, tot zich te laten komen en in zich op te nemen. Zo staat de Geest gedurig en geduldig te kloppen op de deur van het hart. De prins fluit buiten de poort van het kasteel, opdat de slapende prinses wakker zou worden. De vocatio externa wil door alle muren heen penetreren en vocatio interna worden. A.A. van Ruler, 'Ultra-Gereformeerd en Vrijzinnig' in Wapenveld 21/ 2 (1971). Vergelijk de uitgave in de Verzamelde werken Van Ruler, 'Ultra-Gereformeerd en Vrijzinnig' in: Christus, de Geest en het heil, 721-801, 724 . 
dienaar van het Woord mag de prediker, staande in heilzame spanning van Woord en Geest, ontspannen te werk gaan in de wetenschap dat het heil niet van hem afhangt en zelfs niet van de respons van de hoorder, maar van de kracht van de Geest in en met en door het levenscheppende Woord.

H. van den Belt is bijzonder hoogleraar Gereformeerde godgeleerdheid: Bronnen, ontwikkeling en context en universitair hoofddocent Theologiegeschiedenis aan de Rijksuniversiteit Groningen. 